Kasper Kaproń OFM ${ }^{1}$

Katolicki Uniwersytet św. Pawła w Cochabamba, Boliwia

Wydział Teologiczny

\title{
Luis Jerónimo de Oré OFM - Symbolo Catholico Indiano (1598)
}

Luis Jerónimo de Oré Rojas (1554-1630), franciszkański zakonnik i późniejszy biskup Concepción w Chile, to jedna z najwybitniejszych postaci Wicekrólestwa Peru w jego początkowym okresie oraz krystalizowania się struktur kościelnych w Ameryce Łacińskiej. Urodzony w Huamanga (aktualnie na terenie departamentu Ayacucho w Peru) w rodzinie przybyłych do Nowego Świata hiszpańskich osadników: Antonia de Oré y Río i Luisy Diez de Rojas, już w domu rodzinnym otrzymał podstawy starannego wykształcenia humanistycznego i językowego (Antonio był zamiłowanym latynistą). W wieku 14 lat wstąpił do nowicjatu Braci Mniejszych. 23 września 1581 roku otrzymał święcenia kapłańskie z rąk arcybiskupa Limy, późniejszego świętego Turybiusza (Toribio Alfonso de Mogrovejo)². Ze względu na znajomość języka keczua i ajmara uczestniczył w obradach III Synodu Limskiego (1582-1583), gdzie brał aktywny udział w opracowaniu katechizmu dla ludności indiańskiej ${ }^{3}$. Ewangelizował następnie Indian Collaguas zamieszkujących wzgórza Colca ${ }^{4}$. To właśnie pracując na tym terenie, wśród rdzennych mieszkańców Ameryki, napisał swoje najważniejsze dzieła: Symbo-

\footnotetext{
${ }^{1}$ Kasper Kaproń OFM (Prowincja Matki Bożej Anielskiej OFM w Krakowie) — ur. w 1971 roku, doktor liturgiki. Przez kilka lat był duszpasterzem we Włoszech. Od 2001 do 2007 roku odbył studia specjalistyczne na Papieskim Instytucie Liturgicznym św. Anzelma w Rzymie. W latach 2011-2014 pracował na misjach wśród Indian Chiquitos i Guarayos. Obecnie pracownik naukowy, sekretarz generalny i kierownik studiów doktoranckich na Wydziale Teologicznym Katolickiego Uniwersytetu św. Pawła w Cochabamba (Boliwia); e-mail kasper@krakow.home.pl. ORCID: 0000-0002-0054-3414.

2 J.T. Polo, Luis Jerónimo de Oré, „Revista Histórica” 2 (1907), s. 74-91.

${ }^{3}$ E.T. Bartra, Los autores del catecismo del Tercer Concilio Limense, „Mercurio Peruano” 470 (1967), s. 359-372.

${ }^{4}$ A. Tibesar, Franciscan beginnings in Colonial Perú, Washington DC 1953, s. 65.
} 
lo Catholico Indiano, Rituale seu Manuale Peruanum oraz słownik i gramatykę keczua i ajmara (Arte y vocabulario en romance y en las lenguas generales deste reyno quechua y aimara). Opracowania te zyskały wielkie uznanie i Fernando de Trajo, franciszkański przełożony z Limy, w liście datowanym 6 grudnia 1595 roku zwrócił się z prośbą do króla hiszpańskiego o wydanie drukiem rękopisów L.J. Oré jako bardzo przydatnych w nawracaniu Indian5.

L.J. Oré pracował następnie w różnych parafiach indiańskich w Peru. Na początku XVII wieku był uznanym kaznodzieją w Potosí, jednym z największych ówczesnych miast i wielkim ośrodku górniczym ${ }^{6}$. Pełnił funkcję proboszcza parafii indiańskiej w Cuzco, dawnej stolicy imperium Inków. Dostrzegając wartość opublikowanego w 1598 roku w Limie Symbolo Catholico Indiano i popularność, z jaką dzieło to było wykorzystywane w posłudze duszpasterskiej wśród Indian, biskup Cuzco, Antonio de la Raya Navarrete, oddelegował franciszkańskiego zakonnika do Europy. Otrzymał on listy polecające do króla hiszpańskiego i do papieża, z prośbą o ułatwienie publikacji pozostałych rękopisów: zbioru homilii w językach tubylczych, rytuału sakramentów i słownika keczua i ajmara. W czasie audiencji na dworze królewskim i u papieża L.J. Oré otrzymał stosowne pozwolenia, a dodatkowo Ojciec Święty Paweł V udzielił specjalnego odpustu dla wszystkich modlących się pieśniami pochwalnymi i litaniami napisanymi przez L.J. Oré7.

Rituale, seu manuale peruanum zostało opublikowane w Neapolu w 1607 roku. Dzieło to jest księgą liturgiczną zawierającą obrzędy sakramentów z tekstami w językach: ajmara, keczua, pukina, moczika, guarani i brasilika. W czasie pobytu L.J. Oré w Italii ukazało się drukiem także kolejne jego dzieło: Tratado sobre las indulgencias (wydane w Alessandri w 1606 roku). Niestety, brak informacji dotyczących losów publikacji pozostałych dzieł. Także rękopis Arte y gramática de las dos lenguas generales del Perú, quichua y aimara zaginął.

Pod koniec 1611 roku, w czasie pobytu na terenie Italii, L.J. Oré został wyznaczony, aby zebrać grupę misjonarzy z przeznaczeniem do pracy ewangelizacyjnej na Florydzie oraz drugą grupę do pracy wśród Indian zamieszkujących terytorium dzisiejszej Wenezueli. 20 czerwca 1613 roku wraz z pozyskanymi przez siebie nowymi misjonarzami wyruszył w kierunku Florydy, jednakże został zawrócony z wyspy Santo Domingo i powrócił do Hiszpanii, gdzie czekały na niego prace w Generalnym Komisariacie Indii w Sewilli. Na teren Florydy dotarł w 1614 roku jako wizytator generalny tamtejszej prowincji zakonnej oraz klasztorów znajdujących się na Kubie. W czasie pobytu na Florydzie z wielką

${ }^{5}$ R. Levillier, Papeles eclesiásticos de Tucumán, t. 2, Madrid 1926, s. 378.

${ }^{6}$ D. Ocuña, Un viaje fascinante por la América hispana del siglo XVI, Madrid 1969, s. 178.

${ }^{7}$ R. Vargas Ugarte, Historia de culto de María en Iberoamérica y de sus imágenes y santuarios más celebrados, Buenos Aires 1947, s. 80-83. 
gorliwością wypełnił powierzone zadanie: przemierzył teren całej prowincji, wizytując klasztory, i przewodniczył zakonnej kapitule. Owoce swej pracy zawarł w bardzo skrupulatnie sporządzonej relacji wizytacyjnej ${ }^{8}$.

W 1620 roku powrócił do Hiszpanii, aby uczestniczyć w Kapitule Generalnej w Salamance. 17 sierpnia tegoż roku papież Paweł V ogłosił decyzję o mianowaniu L.J. Oré biskupem La Imperial z siedzibą w Concepción (Chile). Najprawdopodobniej jeszcze tego samego roku (choć dokładna data nie jest znana) został konsekrowany w Hiszpanii, a powierzoną sobie diecezję objął na przełomie 1622 i 1623 roku. O jego działalności biskupiej wiemy bardzo mało. Z końcem 1625 lub na początku 1626 roku przeprowadził II synod diecezji, z którego niestety nie zachowały się dokumenty9 ${ }^{9}$. Ponadto, według świadectwa jezuitów, którzy ewangelizowali archipelag Chiloé, stanowiący wówczas najdalej na południe wysunięty punkt diecezji, L.J. Oré, wówczas już siedemdziesięcioletni, z wielkim poświęceniem dokonał wizytacji tej odległej prowincji, ,gdzie spędził rok, będąc dla wszystkich wzorem prawdziwej świętości" ${ }^{10}$. Brak dokumentów stanowiących niezbędny materiał do historycznych poszukiwań można wytłumaczyć tym, że w przeciwieństwie do Santiago, drugiej chilijskiej siedziby biskupiej czasów kolonialnych, obejmującej północne, o wiele spokojniejsze części kraju, teren powierzony pasterskiej trosce L.J. Oré był obszarem, na którym prowadzono liczne wojny: częste pożary i wojenne zawieruchy dokonały nieodwracalnych zniszczeń dokumentów. L.J. Oré zmarł 30 stycznia 1630 roku.

Pełny tytuł najsłynniejszego dzieła L.J. Oré brzmi: Symbolo Catholico Indiano, en el qual se declaran los mysterios de la fe contenidos en los tres Symbolos Cathólicos, Apostólico, Niceno y de S. Athanasio. Contiene assi mesmo una descripción del nueuo orbe, y de los naturales. Y un orden de enseñar la doctrina Christiana en las dos lenguas Generales: Quichue y Aymara, con un Confesionario breve y Cathechismo de la comunión ${ }^{11}$. Powstało ono jako próba rozwiązania problemów, przed którymi stanęli misjonarze przybywający do nowo odkrytego świata, z których najpoważniejszym była trudność w komunikacji z rdzenną ludnością i odpowiedni, w niczym niezniekształcony, przekaz prawd wiary. Wobec

\footnotetext{
${ }^{8}$ Relacja z wizytacji została opublikowana: A. López, Relación histórica de la Florida escrita en el siglo XVII (2 vol.), Madrid 1931.

9 C. Ovifido Cavada, Los obispos de Chile 1561-1978, Santiago 1979, s. 39.

10 N.D. Cook, Luis Jerónimo de Oré: Una aproximación, w: Symbolo Catholico Indiano. Fray Luis Jerónimo de Oré OFM - 1598. Edición facsimilar, ed. A. Tibesar, Lima 1992, s. 35-61, tu: s. 56.

${ }^{1}$ Katolickie Wyznanie Wiary dla Indian, w którym wyttumaczone zostaja tajemnice wiary zawarte $w$ trzech symbolach katolickich: apostolskim, nicejskim iśw. Atanazego. Zawiera też opis Nowego Świata $i$ [mieszkających tam] tubylców. A także porządek nauczania doktryny chrześcijańskiej w najważniejszych językach keczua i ajmara wraz z podręcznikiem dla spowiedników i katechizmem dla przygotowujacych się do Komunii $[=\mathrm{SCI}]$. Wszystkie cytowane fragmenty dzieła według własnego tłumaczenia autora artykułu.
} 
tych trudności III Synod Kościoła w Limie (1582-1583), w którym aktywnie uczestniczył młody wówczas jeszcze L.J. Oré, podjął uchwały nakazujące opracowanie i wydanie katechizmów, tekstów duszpasterstwa liturgicznego (Confesionario, rytuały i modlitewniki) oraz innych tekstów niezbędnych w pracy duszpasterskiej wśród ludności tubylczej. Synod zalecił, aby opracowano tłumaczenia przygotowanych dzieł na języki keczua i ajmara oraz na inne języki używane przez Indian ${ }^{12}$.

L.J. Oré urodzony już w Ameryce, w regionie, gdzie używano języka keczua, pracując następnie w regionach, gdzie dominował język ajmara, był świadomy konieczności posiadania odpowiednich pomocy do pracy wśród Indian. Sam zresztą wspomina w XVII rozdziale Symbolo Catholico Indiano, że jest ono owocem wieloletniej posługi wśród Collaguas i w wielu innych miejscach aktualnego Peru. O wartości tego opracowania świadczy to, że zostało ono w 1601 roku przyjęte jako obowiązujące dla całego duchowieństwa przez synod diecezjalny w Cusco.

Istnieją obecnie trzy udokumentowane egzemplarze Symbolo Catholico Indiano: w londyńskim British Museum, w Bibliotece Narodowej w Santiago de Chile i w Bibliotece Narodowej w Limie (ten ostatni znacznie uszkodzony). W 1992 roku peruwiańskie wydawnictwo Australis wydało reprint dzieła w serii wydawniczej Ars Historiae.

\section{Struktura Symbolo Catholico Indiano}

Dzieło w swej strukturze jest niejednolite i trudno zakwalifikować je do ściśle określonej kategorii. We wstępie autor wskazuje na cel, którym się kierował: przygotowanie duszpasterskiej pomocy $\mathrm{w}$ wyjaśnieniu Indianom prawd wiary, „aby misjonarze wiedzieli, czego należy uczyć tubylców w ich rdzennym języku”" ${ }^{13}$, oraz pragnienie przekazania misjonarzom informacji dotyczących „lokalizacji ziem oraz pochodzenia zamieszkujących te tereny ludów"14. Sam tytuł zresztą najlepiej ukazuje wielotematyczność dzieła: celem autora jest: uporządkować przekaz głównych prawd wiary, przekazać informacje o charakterze geograficznym i antropologicznym oraz pomóc duszpasterzom pracującym wśród Indian $\mathrm{w}$ ich działalności katechetycznej $\mathrm{i} \mathrm{w}$ posłudze sakramentalnej. Jest to rozbudowany podręcznik katechetyczny o następującej strukturze:

12 J.G. Durán, El Catecismo del III Concilio Provincial de Lima y sus Complementos Pastorales (1584-1585). Estudio preliminar, textos, notas, Buenos Aires 1982, s. 48.

13 SCI, Prohemio.

14 Tamże. 


\section{Teologia zbawienia}

Pierwsze strony tekstu to piękna medytacja teologiczna, zbudowana na schemacie Katechizmu Rzymskiego i rozpoczynająca się traktatem „O poznaniu Boga, w którym to mamy życie wieczne"15. Autor opisuje naturalną tęsknotę człowieka, jaką jest pragnienie osiągnięcia szczęścia i życia wiecznego, i wskazuje na Jezusa Chrystusa jako na drogę ku zaspokojeniu tych pragnień. Autor proponuje następnie indukcyjne dojście do wiary: „Do poznania Boga można dojść przez rozważanie świata stworzeń, choć w doskonalszy sposób dochodzi się w świetle Objawienia"16. W duchu Franciszkowej Pieśni Słonecznej opisuje „księgę przyrody, gdzie znajdują się niezliczone litery różnych stworzeń, zapisane na czterech kartach, w których zawarta jest wielość rodzajów i zróżnicowanych natur" ${ }^{17}$. Pierwsza karta to byty nieożywione, które można uporządkować według czterech elementów greckiej kosmologii (ziemia, woda, powietrze i ogień). Druga karta księgi przyrody to stworzenia, które „posiadają duszę wegetatywną, ponieważ żywią się z ziemi, rodzą się z niej i z niej ciagna pokarm i w ten sposób wzrastają" ${ }^{18}$. Trzecia karta to „stworzenia, którym brakuje jedynie zdolności rozumienia i wolnego wyboru, posiadają jednak istnienie, życie i zmysły: zdolność widzenia, słyszenia, węchu, smaku i dotyku”19. Czwartą jest „człowiek stworzony na obraz i podobieństwo Boże, który posiada istnienie, życie, uczucie, zrozumienie, zdolność mówienia, wolną wolę i umie wybierać między tym, co chce, a tym, czego nie chce"20. L.J. Oré podkreśla, że ,istnieje tylko jeden gatunek ludzki i wszyscy ludzie, niezależnie od rasy, posiadają tę samą ludzką naturę: posiadają wolność decyzji i wyboru, która to cecha wyróżnia człowieka spośród innych bytów stworzonych i to ona określa jego najwyższą godność" ${ }^{21}$. Temat wolności woli, dzięki której człowiek w najwyższym i w najpełniejszym stopniu upodobnia się do Boga, zostaje rozwinięty w kolejnym rozdziale zatytułowanym „Powody spójności istoty Boga, Jego doskonałości i boskie atrybuty”22. Posiadany przez człowieka dar wolności decyzji w sposób najpełniejszy upodabnia go do Boga i sprawia, że jedynie Bóg może zaspokoić wszelkie aspiracje i ludzkie tęsknoty.

Odkrywając Boga przez byty stworzone, człowiek dochodzi do poznania tajemnicy Trójcy Świętej (rozdz. IV). To właśnie jedność i różnorodność stwo-

\footnotetext{
15 SCI: f. $1 \mathrm{r}$.

16 SCI: f. 2 v.

17 Tamże.

18 SCI: f. 4 r.

19 Tamże.

${ }^{20}$ SCI: f. $4 \mathrm{v}$.

${ }^{21}$ SCI: f. 5 r.

${ }^{22}$ SCI: f. 7 r.
} 
rzonego świata ukazuje istotę i naturę rzeczywistości niewidzialnej, odwiecznej i najdoskonalszej, jaką jest Najświętsza Trójca ${ }^{23}$. Kolejny rozdział ukazuje Boga jako inicjatora historii zbawienia, którą kontynuuje Kościół w działalności misyjnej. Pragnąc wytłumaczyć misjonarzom ewangelizującym Indian znaczenie ich trudnej i niebezpiecznej pracy, L.J. Oré tworzy teologię misji: wskazuje na ścisłą łączność dzieła Ducha Świętego w działalności misyjnej z dziełem zbawczym Jezusa Chrystusa ${ }^{24}$.

W rozdziale VI „Rozważanie o tym, jak człowiek po grzechu został odkupiony przez drogocenną śmierć Chrystusa naszego Odkupiciela"25 autor przedstawia historię zbawienia, poczynając od stworzenia aniołów i buntu niektórych z nich, tragicznego w skutkach kuszenia i upadku człowieka. Tajemnica Wcielenia to odpowiedź Boga, który w ten sposób w swojej wielkiej mądrości ratuje stworzenie z upadku grzechu.

L.J. Oré kończy ten rozdział przypomnieniem ewangelicznego nakazu misyjnego, ,aby wszyscy ludzie mogli poznać Boga”. Jednocześnie w pełnych współczucia słowach opisuje sytuację Indian cierpiących krzywdy z rąk kolonizatorów i potępia wszelkie formy wyzysku:

Błogosławieni ci, którzy porzuciwszy już ciemności śmierci, weszli na drogę zbawienia i kierują swe kroki ku życiu wiecznemu. Nieszczęśliwi ci, którzy mieszkają jeszcze w mrokach śmierci na obszarach Indii Zachodnich, gdzie dominuje siła oręża, a pragnienie zysku jest silniejsze niż połów dusz odkupionych przez krew Baranka bez skazy. O jakże nieszczęśliwi są tubylcy, a jakże nieszczęśliwy ich los, do którego zostali zepchnięci. Brakuje pasterzy i stróżów, którym Chrystus powierzyłby swoje owce [...] Brak licznych nawróceń wśród Indian to świadectwo mówiące o tym, że sprawy mogące służyć ich zbawieniu traktowane są jako coś drugorzędnego. Ci, którzy przybyli na te ziemie, myślą tylko o tym, jak wykorzystać tych biednych Indian w pracach na plantacjach i w innych ciężkich pracach, tak że nie mają niemal jednej chwili wytchnienia w ciągu roku. I tak przez całe życie. Nie mogą poznać Chrystusa i wielu z nich umiera na skutek nadludzkiego wysiłku, do jakiego są zmuszani...26.

\section{Antropologia kulturowa}

Rozdział VII, błędnie oznaczony jako VIII, nosi tytuł „Opis kraju i ludów zamieszkujących Peru”. Autor na kilkunastu stronach przedstawia geograficzny opis

${ }^{23}$ SCI: f. 9 v.

${ }^{24}$ SCI: ff. 12 v. -15 v.

${ }^{25}$ SCI: f. $16 \mathrm{r}$.

${ }^{26}$ SCI: f. 19 r. 
Ameryki, ukazując ją jako część stworzonego świata. W opisach geograficznych miejsc czerpie z informacji przekazanych przez odkrywców i konkwistadorów i wskazuje na cytowane przez siebie źródła. Przedstawia dotychczasowy zasięg konkwisty i kończy w tonie optymistycznym, opisując proces działalności misyjnej wśród Indian, którzy przyjmują wiarę ,,wolną od błędów i fałszywych herezji”'27.

W rozdziale VIII autor opisuje „ludy i miasta, które znajdują się w górach Peru, a także rzeki, kopalnie i inne ciekawostki tego królestwa". Podkreśla znaczenie sanktuariów maryjnych w Copacabana (Boliwia) i w Trujillo. To drugie miejsce to wielki ośrodek kultu maryjnego ludności hiszpańskiej i Indian Yuncas z Moche. $\mathrm{Z}$ wielkim entuzjazmem L.J. Oré opisuje swoje rodzinne strony Huamanga, gdzie:

znajduje się najpiękniejsza świątynia i najpiękniejsze niebo w całym królestwie Peru; gdzie ziemia każdego roku wydaje tysiące ton pszenicy, bogata jest we wszystkie owoce znane w Castilli oraz w innych częściach świata; gdzie znajdują się wielkie rancza pełne bydła, owiec i kóz; ziemia jest pełna wspaniałych winnic i produkuje się najlepsze wino. Znajdują się tam liczne kopalnie srebra i innych minerałów; to właśnie tam na swojej ziemi mój ojciec Antoni odkrył wielkie złoża srebra, które wydobywał i dzięki którym ufundował klasztor św. Klary. Znajdujące się tam pokłady cennego kruszcu zabezpieczyły całość prac, aby móc bez przeszkód ukończyć budowę klasztoru, i kiedy prace zostały zakończone, także metal w kopalni się skończył i już nie wydobyto z niej ani reala ${ }^{28}$.

Rozdział IX opisuje „Pochodzenie i warunki życia peruwiańskich Indian”29. Autor ukazuje istniejące różnice pomiędzy poszczególnymi grupami etnicznymi zamieszkującymi terytorium Peru. Opisuje ponadto różnice występujące wewnątrz poszczególnych grup, a wynikające z przynależności do określonych warstw społecznych. Dużo uwagi poświęca cywilizacji Inków, którzy dzięki ukształtowanej kulturze prawnej i systemowi rządzenia stali się dla innych ludów tym, „czym był poeta Solon dla Ateńczyków”. Następnie opisuje system wierzeń religijnych ludności indiańskiej i dokonuje rozróżnienia na pierwotny system politeistyczny oraz monoteizm wprowadzony przez Capaca Yupanqui. Przejście z politeizmu do monoteizmu było konsekwencją filozoficznej refleksji tego inkaskiego wodza. Ponieważ Inkowie czcili słońce, więc należy przyjąć, że istnieje przyczyna, która doprowadziła do zaistnienia słońca, którym - według Capaca - jest Pachacamac, to znaczy Stwórca Wszechświata. W tekście zostaje

\footnotetext{
27 SCI: ff. 22 v. $-30 v$.

28 SCI: f. 32 r.

29 SCI: ff. 37 r. -42 v.
} 
przytoczony fragment modlitwy ułożonej przez Capaca Yupanqui, rozpowszechnianej następnie za pozwoleniem biskupów przez chrześcijańskich misjonarzy:

O Stwórco, który istniejesz od założenia i początku świata i który rozciągasz swoje panowanie aż do krańców świata. O potężny, bogaty, miłosierny, który powiedziawszy: „Niech on stanie się mężczyzną”, powołałeś do istnienia mężczyznę, a powołując do istnienia kobietę, powiedziałeś: „Niech stanie się kobietą”; i nadałeś kształtów kobiecie i mężczyźnie. Strzeż teraz te Twoje dzieła, niech żyją w zdrowiu i w bezpieczeństwie, z dala od wszelkiego zagrożenia i w pokoju ${ }^{30}$.

L.J. Oré nawiązuje do tej modlitwy i do systemu wierzeń Inków i choć nie używa tego określenia, to wskazuje na nie jako na autentyczne semina verbi. Podobnie jak św. Paweł na ateńskim Areopagu odniósł się do świata wierzeń starożytnych Greków, misjonarze ewangelizujący ludy Ameryki powinni w przekazie wiary chrześcijańskiej oprzeć się na pierwotnej religii ewangelizowanych ludów. Rozdział ten L.J. Oré kończy, pisząc o „wielkim bólu”, który powinien zjednoczyć Indian, osoby duchowne oraz Hiszpanów z powodu egzekucji Túpaca Amaru, ostatniego przywódcy Inków straconego w Cuzco w 1572 roku na rozkaz wicekróla Toledo. Jednocześnie jednak wyraża wdzięczność wicekrólowi za

system redukcji, dzięki którym wiele rozproszonych indiańskich ludów zostało zgromadzonych w jedno, co ułatwiło przekaz doktryny i pozwoliło ludy te otoczyć duszpasterską opieką. Misjonarze, żyjąc wśród Indian, pomagają uwolnić się im ze złych skłonności, takich jak pijaństwo i rozwiązłość. I chociaż niedawno jeszcze oddawali oni cześć słońcu i księżycowi i skłonni byli do innych form bałwochwalstwa, to dzisiaj króluje wśród nich Chrystus. Dokonało się to na terenach, gdzie zaledwie 100 lat temu, a nawet mniej, ludność poddana była pod władzę diabła. Jednakże dużo jeszcze pracy przed misjonarzami, gdyż wiele indiańskich ludów nie zna Chrystusa, a i wśród tych, którzy Go już poznali, wiara jest nieugruntowana ${ }^{31}$.

\section{Duchowość misyjna}

Rozdział X „O pasterskiej trosce i misyjnym zapale charakteryzujących ministrów świętej Ewangelii w nawracaniu Indian zamieszkujących ten nowy świat" rozpoczyna się od przepięknej medytacji biblijnej na temat posługi przepowiadania Słowa. L.J. Oré wskazuje na trzy cechy, które powinny charakteryzować prawdziwego misjonarza: „wierność doktrynie, świętość życia, ojcowska troska

\footnotetext{
${ }^{30}$ SCI: f. $40 \mathrm{r}$.
}

${ }^{31}$ SCI: f. 42 r 
względem Indian"32. Głównym zadaniem misjonarza jest głosić światu Chrystusa Ukrzyżowanego, który umarł dla zbawienia człowieka, i być świadkiem Jego chwalebnego zmartwychwstania. Rozdział ten kończy się słowami: „[t]ak jak Pan polecił Apostołom głosić Ewangelię po całym wówczas znanym świecie, tak poleca nam głosić ją na tej nowo odkrytej ziemi”’33.

Rozdział XI jest egzortacją i zachętą do lektury bardzo popularnego wówczas traktatu na temat modlitwy napisanego przez dominikanina, Ludwika z Granady $(1504-1588)^{34}$.

\section{Praktyczne wskazania dotyczące katechezy}

Począwszy od rozdziału XII, autor przedstawia liczne zagadnienia praktyczne związane z katechezą i przekazem doktryny. Rozdział XII nosi tytuł „O wystroju kościołów i ołtarzy" i dotyczy konieczności wznoszenia odpowiednich budynków sakralnych, tak aby:

mogli się w nich gromadzić Indianie na Mszy Świętej i gdzie będą mogli słuchać Słowa Bożego. Brak świątyń powoduje bowiem, że asystują świętym czynnościom w deszczu i w słońcu, cierpiąc z powodu zimna i gorąca, jak to bywa w miejscach, gdzie nie ma kościołów, a jedynie jakieś prowizoryczne baraki niegodne spraw tak ważnych i świętych ${ }^{35}$.

Autor wyraża wdzięczność królowi za stałą troskę o sprawy kultu, pomijając zupełnie to, że należało to do jego obowiązków, gdyż na potrzeby godnego sprawowania liturgii pobierano w Królestwie dziesięcinę.

Nawiązując do dekretów III Synodu Limskiego z 1583 roku mówiących o roli śpiewu i muzyki w przekazie wiary, L.J. Oré radzi, aby każda misja miała grupę kantorów oraz osoby przygotowane w prowadzeniu chórów, a także potrafiących grać na organach i innych instrumentach, takich jak flety, oboje i trąbki, „przede wszystkim w celu nawracania Indian i utwierdzania ich w wierze katolickiej, jaką otrzymali od Świętego Kościoła Rzymskiego"36.

Temat śpiewu i muzyki autor kontynuuje w rozdziale XIII „O modlitwach i o śpiewach, jakie należy wykonywać w chórze, oraz o tym, w jaki sposób należy przekazywać doktrynę”. L.J. Oré przypomina misjonarzom, że „głównym ich obowiązkiem, kiedy przebywają wśród ludności indiańskiej, jest śpiewać razem

${ }^{32}$ SCI: f. 43 r.

33 SCI: f. $46 \mathrm{v}$.

${ }^{34} \mathrm{SCI}$ : ff. $47 \mathrm{r}$ - $-50 \mathrm{r}$.

${ }^{35}$ SCI: f. $50 \mathrm{v}$.

36 SCI: f. 52 r. 
z nimi, z nimi modlić się i uczyć ich w ten sposób prawd wiary świętej" ${ }^{37}$. Pisząc o obowiązku katechizacji, wskazuje na konieczność objęcia nim wszystkich dorosłych i dzieci. Spotkania katechetyczne powinny odbywać się trzy razy w tygodniu (w niedzielę, w środy i w piątki), a gdy z różnych przyczyn nie można zagwarantować tej częstotliwości, to w żadnym wypadku nie można dopuścić do zaniedbywania spotkań niedzielnych: ,[j]est to konieczne, aby zaspokoić słuszny głód Indian w zdobyciu wiedzy i nauczyć ich, jak śpiewem wychwalać Boga"38. Zgodnie z zaleceniami III Synodu Limskiego nakazującymi publiczną pokutę Indianom, którzy na skutek lenistwa nie uczą się katechizmu, autor sugeruje prace porządkowe w kościele dla niechętnie uczących się indiańskich wodzów, osób posiadających władzę i kobiet. W odniesieniu do pozostałych należy stosować kary fizyczne (chłostę):

w sposób surowy, a jednocześnie z miłosierdziem, tak aby kara ta nie była zbyt dotkliwa, ale jednocześnie też nie wywoływała jedynie śmiechu, by miała realny wpływ na poprawę i była skuteczna, czyli aby dzięki niej osoby leniwe zostały zmotywowane do pracy i nauki katechizmu. Dzieci w wieku szkolnym należy częściej egzaminować i tych, którzy nie uczą się, należy odpowiednio karać, tak jak tego wymaga dyscyplina, ale zawsze odpowiednio do ich wieku³ ${ }^{39}$.

Należy jednak motywować do zdobywania wiedzy przede wszystkim przez piękno, a nie jedynie budząc strach i lęk przed karą. Dlatego też wioski należy wypełnić muzyką religijną i pięknem: ,[k]ażdego wieczoru, po kończącej dzień modlitwie, niech dzieci uczące się katechizmu wyjdą na plac w procesji i niech śpiewają, zatrzymując się na modlitwę za dusze w czyśćcu cierpiące na każdym rogu placu"40.

W organizacji przekazu wiary i szkolnictwa L.J. Oré idzie o wiele dalej, niż było to wymagane w ówczesnej Hiszpanii, i zaleca tworzenie szkół w każdej wiosce:

Jest wręcz konieczne, aby w każdej wiosce istniała szkoła, gdzie będzie przekazywana uczniom doktryna, gdzie będą mogli nauczyć się czytać i pisać, śpiewać i grać na instrumentach, gdzie nauczą się zawodu i rękodzieła, aby w przyszłości sami mogli stać się nauczycielami. Taka szkoła jest sercem całej wioski. To dzię-

37 SCI: f. 52 v.

38 SCI: f. 54 r.

${ }^{39}$ SCI: f. 55 r.

40 SCI: f. 55 v. 
ki niej wszyscy będą mogli poznać świętą wiarę Kościoła i nauczą się uwielbiać

Boga śpiewem w kościołach, przy ołtarzu i w codziennym życiu ${ }^{41}$.

\section{Katecheza sakramentalna i odnosząca się do pobożności ludowej}

Rozdział XIV nosi tytuł „Jak należy śpiewać Salve w sobotę wieczorem oraz o innych kwestiach dotyczących kultu Naszej Pani zawsze Dziewicy Maryi”. L.J. Oré pisze, że ,jest chwalebne i właściwe, aby w każdym kościele indiańskim znajdowała się figura Matki Najświętszej i jeśli jest to możliwe, aby był poświęcony ku Jej czci ołtarz lub kaplica, tak aby Indianie z wielką pobożnością mogli zwracać się do Niej w każdej potrzebie". L.J. Oré zobowiązuje księży, aby wytłumaczyli ludziom znaczenie śpiewu Salve i aby nauczyli ich modlitwy różańcowej. Sugeruje, aby „główne święta maryjne obchodzone były w wioskach w sposób uroczysty ze śpiewanymi Nieszporami w wigilię, z uroczystą Mszą Świętą, z procesją oraz z kazaniem"42.

Krótki rozdział $\mathrm{XV}$ poświęcony jest modlitwom za dusze w czyśćcu cierpiące oraz Mszy Świętej w ich intencji, którą franciszkanie celebrowali w każdy poniedziałek wraz z procesją za zmarłych, z własnymi responsoriami i modlitwami ${ }^{43}$.

W ostatnim rozdziale tej sekcji zatytułowanym „O udzielaniu świętych sakramentów Kościoła" autor odsyła czytelnika do swojego dzieła Manual Peruano, które — ma nadzieję — w najbliższym czasie ukaże się drukiem wraz ze zbiorem homilii na niedzielę i święta całego roku w języku hiszpańskim oraz w ajmara i keczua ${ }^{44}$. Los zbioru homilii w trzech językach nie jest znany, natomiast sam Manual Peruano jest prawdziwą perłą bibliofilską i unikatowym dokumentem pozwalającym poznać historię liturgii i misji w Ameryce Łacińskiej.

Autor zwraca uwagę duchownym, aby z należnym szacunkiem podchodzili do spraw związanych z sakramentami, dokładnie znali formułę każdego z sakramentów oraz orientowali się w głównych trudnościach związanych $\mathrm{z}$ ich administracją. Wskazuje na konieczność zorganizowania życia misji w taki sposób, aby były w niej osoby odpowiedzialne, które każdego ranka mogłyby poinformować pracujących w niej duszpasterzy o nowo narodzonych dzieciach, aby w sytuacji zagrożenia życia móc je natychmiast ochrzcić. Do zadań osób odpowiedzialnych należało także informowanie o osobach chorych, aby nikt nie umarł pozbawiony sakramentów, ale także aby kapłan mógł zatroszczyć się o zdrowie chorego, gdyż „Indianie nie mają nikogo innego, kto mógłby pomóc im w chorobie” ${ }^{45}$.

${ }^{41}$ SCI: f. 56 r.

42 SCI: f. $57 \mathrm{v}$.

${ }^{43}$ SCI: ff. 57 v. -58 r.

${ }^{44}$ SCI: f. 59 r.

${ }^{45}$ SCI: f. $60 \mathrm{r}$. 
Autor poświęca sporo miejsca tematowi zdrowia fizycznego i psychicznego duchownych i zaleca im, aby

byli osobami uporządkowanymi i dbali należycie o porządek dnia [...] nie może zabraknąc czasu na modlitwę osobistą i brewiarz; czasu, aby spowiadać chorych i zdrowych, aby odwiedzać chorych i udzielać im sakramentów, aby sprawować Mszę i uczyć katechizmu, ale także nie może zabraknąć czasu, aby odpocząć od tych szlachetnych prac, gdyż ciało nie jest ze stali i musi odpocząć, dusza zaś jest diamentem, który wymaga codziennego i wytrwałego szlifowania przez odpoczynek w ciszy modlitwy ${ }^{46}$.

Zaleca także, aby misjonarz znał dobrze rdzenny język Indian, wśród których pracuje, i udziela praktycznych wskazówek odnoszących się do pracy w misji:

Misjonarz nie powinien otaczać pasterską troską więcej niż czterysta, a co najwyżej pięćset osób, gdyż niemożliwe jest spowiadać tak wielką liczbę i należycie troszczyć się o ich życie sakramentalne. Dlatego też w przypadku większej liczby mieszkańców w wioskach prowincjałowie powinni zadbać, aby było tam dwóch lub więcej kapłanów ${ }^{47}$.

\section{Użyteczność dzieła}

W rozdziale XVII „O użyteczności Symbolo Catholico Indiano"48 autor opisuje własne doświadczenie pracy misyjnej wśród Indian Collaguas oraz w innych miejscach regionu powierzonych Braciom Mniejszym. To właśnie to żywe i bezpośrednie doświadczenie stanowi podstawy do opracowania niniejszego dzieła. Wskazuje także na cel opracowania, jakim jest ,uwolnienie Indian z wszelkich form przesądu i zabobonu przeciwstawiających się wierze katolickiej i ukazanie piękna życia uczciwego, gdy poznają Boga i Jego Syna Jezusa Chrystusa"49. Przedstawienie Boga należy rozpocząć od ukazania całego dzieła stworzenia świata. Następnie należy przedstawić upadek człowieka i dzieło zbawienia, którego dokonał Jezus Chrystus. Omówienie dzieła stworzenia jest o tyle istotne, że pomaga Indianom odejść od religii naturalistycznych, w których „elementy kosmiczne, takie jak słońce, księżyc lub górskie szczyty i wulkany uznawane są za bóstwa, i zrozumieć, że są to byty stworzone przez Jedynego Boga" ${ }^{50}$.

\footnotetext{
46 Tamże.

47 SCI: f. $61 \mathrm{r}$.

48 SCI: ff. 61 v.-64 v.

49 SCI: f. 62 r.

50 SCI: f. 62 v.
} 
W ostatnim XVIII rozdziale tej części autor poddaje całość opracowania ocenie i weryfikacji Świętego Kościoła Rzymskiego i informuje czytelnika, że pisząc to dzieło, korzystał z uwag i wskazówek nie tylko swoich franciszkańskich współbraci pracujących wśród Indian (imiennie wymienia Pedra, Antonia oraz Dionisia de Oré), ale także członków innych zakonów (dominikanów, augustianów, jezuitów). Cenne wskazówki otrzymał także od samych Indian. Dzieło to jest owocem wielu lat pracy i dogłębnego studium ${ }^{51}$.

\section{Teologia siedmiu pieśni}

Strony 67 r.-69 v. zawierają tekst Credo św. Atanazego Quiqumque. Tekst tego Wyznania Wiary od średniowiecza rozpowszechniony był w Kościele na równi z symbolem apostolskim i nicejskim i był jedną z najpopularniejszych formuł liturgicznych. Symbolo Catholico Indiano zawiera tekst łaciński oraz tłumaczenie na język keczua. Na podstawie tego tekstu L.J. Oré tworzy siedem pieśni stanowiących wykład wiary chrześcijańskiej. Każda z nich przeznaczona jest na inny dzień tygodnia. Teksty zostały dostosowane do mentalności rdzennych mieszkańców Peru i zawierają liczne odniesienia do kultury i antropologii andyjskiej. Symbolo zawiera teksty pieśni w języku łacińskim, keczua i ajmara z rozbudowanym komentarzem w języku hiszpańskim.

\section{Pieśń pierwsza: Trójca Święta (przeznaczona na niedzielę) $)^{52}$}

Pierwsza pieśn to rozbudowany komentarz do pierwszej części atanazjańskiego Wyznania Wiary: Fides autem catholica haec est, ut unum Deum in Trinitate et Trinitatem in unitate veneremur... Ze względu na trudność w wythumaczeniu ludności indiańskiej dogmatu Trójcy Świętej L.J. Oré świadomie rezygnuje z prób dostosowania tej tajemnicy do mentalności peruwiańskich Indian i przedstawia ją z wykorzystaniem terminologii obowiązującej w teologii katolickiej.

Pieśń druga: Stworzenie świata (poniedziałek) $)^{53}$

Prawda o stworzeniu, temat drugiej pieśni, została dostosowana do mentalności ewangelizowanych ludów. Autor pyta:

\footnotetext{
${ }^{51}$ SCI: ff. 64 v. $-66 \mathrm{r}$

52 SCI: ff. $69 \mathrm{v} .-72 \mathrm{r}$

${ }^{53}$ SCI: ff. 72 r. -79 v.
} 
czy przypadkiem Bóg uczynił ziemię i wszystko, co na niej istnieje, z jakichś elementów przeniesionych skądś indziej $[\ldots]$ czy zbiorniki zostały wypełnione wodą przeniesioną z innego miejsca. Ludzie, budując domy, najpierw muszą zgromadzić odpowiedni materiał; muszą zebrać kamienie i drewno konieczne do budowy, wykopać rowy i wznieść fundamenty. Wznosząc budynek, pomagają sobie wzajemnie i praca ta związana jest z wielkim wysiłkiem. Także później, gdy budynek zostanie już wzniesiony, wymaga dalszej troski i konserwacji: mury kruszeją, drzewo gnije. Pan Bóg natomiast do stworzenia świata nie używał żadnego materiału, wszystko stworzył z niczego mocą swego słowa ${ }^{54}$.

Elementy kosmosu: „słońce, księżyc, gwiazdy i górskie szczyty”, oraz wszelkie dzieła rąk ludzkich zostają ukazane jako byty stworzone i oddawanie im czci jest hołdem składanym fałszywym bogom. Znając możliwości percepcyjne swoich neofitów, L.J. Oré materializuje rzeczywistość życia wiecznego:

Ponad tym niebem, które widzimy, znajduje się wyższe niebo, piękniejsze niż wszystko inne, lśniące bardziej niż złoto, krystaliczne i przejrzyste. Jest to niebo, które jest mieszkaniem i tronem Boga Najwyższego, uczynione przez Niego samego, aby mogło być mieszkaniem Jego chwały ${ }^{55}$.

Materializuje także świat demonów:

Wszystkie te duchy wraz ze swym księciem szatanem zostały strącone do piekieł, a niektóre z nich ukryły się w miejscach ciemnych i podstępnych, skąd starają się nas oszukać, abyśmy dali się zwieść i popełnili grzech ${ }^{56}$.

\section{Pieśń trzecia: Stworzenie czlowieka, grzech i odkupienie (wtorek) ${ }^{57}$}

Jest to piękna antologia tekstów biblijnych w formie modlitwy uwielbienia. Zgodnie z duchem epoki prawda o stworzeniu człowieka i jego upadku została przedstawiona w dosłownym znaczeniu opowiadań biblijnych. Dostrzec jednak można także elementy teologii patrystycznej: „Dla nas, ludzi, stałeś się człowiekiem, aby ludzie dzięki Twej miłości i łasce stali się synami Boga ${ }^{58 " .}$

Znaczna część pieśni jest poświęcona uwielbieniu Matki Najświętszej: „[d]zięki Tobie, Matko, chrześcijanie na całej ziemi oddają cześć świętej Trój-

${ }^{54}$ SCI: f. $72 \mathrm{v}$.

55 SCI: f. $73 \mathrm{v}$.

56 SCI: f. 74 r.

57 SCI: ff. 80 r.-91 r.

58 SCI: f. $81 \mathrm{r}$. 
cy, i dzięki Tobie adorują i błogosławią w każdym miejscu drogocenny krzyż $\dot{z}^{59 "}$. Piękno Matki Bożej opisuje za pomocą porównań do drzew i kwiatów rosnących w Nowym Świecie. Są to odniesienia występujące w litanii, którą ułożył L.J. Oré i która stała się inspiracją w maryjnej ikonografii kolonialnej ${ }^{60}$.

\section{Pieśń czwarta: Wcielenie Chrystusa (środa) ${ }^{61}$}

Temat wcielenia Syna Bożego został ukazany w ścisłej zależności od Symbolu św. Atanazego. L.J. Oré, nawiązując do patrystycznej szkoły św. Jana Damasceńskiego, podkreśla rolę cielesnego dziewictwa Bożej Rodzicielki. Równocześnie stawia silny akcent na chrystologiczną prawdę, że Jezus Chrystus „przed wszystkimi wiekami, przedwiecznie” jako Bóg został zrodzony z Boga Ojca bez uczestnictwa matki: Deus est ex substantia Patris ante secula genitus, et homo est ex substantia matris in seculo natus ${ }^{62}$. Silny akcent $\mathrm{w}$ tej kwestii wynika ze skłonności ludności indiańskiej do przesadnie rozbudowanego kultu maryjnego. Opierając się na tekstach ewangelicznych opisujących dzieciństwo Jezusa, L.J. Oré wskazuje na potęgę imienia Jezus, „przed którym uciekają demony i drżą wszelkie duchy zagrażające człowiekowi, które oddalają się, gdy tylko zabrzmi to najświętsze imię"63. W kończących strofach pieśni powraca do uwielbienia Matki Najświętszej, która jest „Matką Tego, który uczynił niebiosa i ziemię i morze, a także wspaniałe i bogate pałace, które Bóg przeznaczył jako przyszłe mieszkanie dla sług swoich" ${ }^{64}$.

\section{Pieśń piąta: Stworzenie czlowieka i ziemskie życie Chrystusa (czwartek) ${ }^{65}$}

Jest to pieśń o bardzo silnym podłożu antropologicznym i ma na celu przedstawić argumenty przeciw „fałszywym opiniom, które w temacie stworzenia istnieją wśród Indian”66. Uroczysty prolog wskazuje na cel pieśni: „[s]łuchajcie głosu tego, Indianie, abyście poznali jedynego Boga i odwrócili się już na zawsze od diabła i przestali czcić bożków, tak jak to czynili wasi ojcowie, oddając cześć słońcu, księżycowi i szczytom górskim ${ }^{67}$ ". W dalszej części pieśni autor przeciwstawia się zdecydowanie wszelkim formom mitologizacji i przebóstwienia wład-

\footnotetext{
59 SCI: f. $81 \mathrm{v}$.

60 SCI: f. 83 r.

61 SCI: ff. 91 v.-106 v.

62 SCI: f. $91 \mathrm{v}$

63 SCI: f. 94 v.

64 SCI: f. $105 \mathrm{v}$.

65 SCI: ff. $106 \mathrm{v}-124 \mathrm{v}$.

66 SCI: f. $106 \mathrm{v}$.

67 SCI: f. 107 r.
} 
ców inkaskich, odnosząc się, choć bez nominalnego wskazania, do postaci założyciela państwa Inków Manco Cápaca, który nakazał czcić się jako syn słońca:

Żaden z królów i władców świata nie miał nadzwyczajnego początku i narodzin, ponieważ wszyscy ludzie rodzą się w ten sam sposób i wszyscy w ten sam sposób kończą swój żywot na tym świecie [...] Mówić zatem, że pierwsi Indianie powstali w Pacaritambo [gdzie według mitologii inkaskiej powstali pierwsi ludzie] albo w jakiejś grocie lub też na brzegu jakiejś rzeki, nie jest prawdą i opowieści te należy włożyć między bajki, gdyż nie posiadają żadnego fundamentu prawdy ${ }^{68}$.

I dodaje:

Prawdą jest jednak, że wszyscy jesteśmy dziećmi wywodzącymi się z dwojga prarodziców Adama i Ewy. Dzieci Adama i Ewy zgodnie z poleceniem Boga zaczęly łączyć się w pary i w ten sposób wszyscy ludzie przychodzą na ten świat ${ }^{69}$.

Autor na podstawie 11 pierwszych rozdziałów Księgi Rodzaju i obowiązującej wówczas wykładni tekstu biblijnego ukazuje biologiczne początki ludzkości. Bez głębszych wyjaśnień przypomina, że „ci, którzy nie przyjmą chrztu i nie wejdą przez sakrament do wspólnoty Kościoła, skazują się na wieczne potępienie w ogniu piekielnym"70.

W pieśni przedstawia także ziemskie życie Chrystusa i kolejny raz przypomina o obowiązku przyjęcia chrztu oraz o konieczności postępowania według przykazań Bożych, ,aby móc uczestniczyć w Bożej uczcie”.

\section{Pieśń szósta: Lament duszy rozpamiętującej Mękę Pańską (piątek) ${ }^{71}$}

Piątek to dzień poświęcony rozpamiętywaniu Męki Pańskiej. Modlitwy oraz pełne sentymentalnej tkliwości kazania pasyjne stanowiły stały element serafickiej duchowości, którą franciszkańscy misjonarze rozpowszechnili na terenie Ameryki Południowej. Pieśń napisana przez L.J. Oré wpisuje się w ten kontekst, stając się elementem pasyjnej pobożności ludowej.

${ }^{68}$ SCI: f. $107 \mathrm{v}$.

${ }^{69}$ SCI: f. $108 \mathrm{r}$.

${ }^{70}$ SCI: f. 108 v.

${ }^{71}$ SCI: ff. 125 r.-145 r. 
Pieśń siódma: Zmartwychwstanie i wniebowstąpienie Chrystusa; Zesłanie Ducha Świętego; założenie Kościoła i eschatologia (sobota $)^{72}$

Tematy z zakresu eklezjologii, praktyki sakramentalnej i eschatologii zostają przedstawione w kontekście wydarzenia paschalnego: Zmartwychwstania i Zesłania Ducha Świętego. Dzięki przepowiadaniu Apostołów i udzielanemu przez nich sakramentowi chrztu

mamy chrześcijan i to zgromadzenie nazywane jest Kościołem [...] Biskupi i kapłani, wyznawcy i dziewice, w końcu wszyscy święci mężczyźni i kobiety tworzą prawdziwą świątynię Boga. Także my, żyjący jeszcze na tym świecie, przez sakrament chrztu stajemy się dziećmi Bożymi i członkami Kościoła ${ }^{73}$.

Ostatnie strony tekstu (ff. 156 v.-193 r.) zawierają skrócony katechizm w formie pytań i odpowiedzi w wersjach hiszpańskiej, keczua i ajmara oraz podstawowe modlitwy (Ojcze nasz, Zdrowaś Maryjo, Salve, litanie itd.) także w tych trzech wersjach językowych.

\section{Zakończenie}

Julián Heras w swojej pracy na temat wkładu franciszkanów w ewangelizację Peru, przedstawiając działalność L.J. Oré, wskazuje na Symbolo Catholico Indiano jako na próbę urzeczywistnienia „franciszkańskiej utopii” na terenie ewangelizowanej Ameryki. Miałaby ona polegać na zbudowaniu wśród Indian Kościoła opartego na modelu wspólnoty czasów apostolskich, Kościoła w pełni duchowego, z dala od wszelkich podziałów tak dotkliwie raniących chrześcijan w Europie ${ }^{74}$. Głębsza analiza tekstu pozwala wychwycić odniesienia do idei joachimizmu; dostrzec można liczne nawiązania do trójpodziału dziejów i okresu Ducha Świętego, który miał wkrótce - na terytorium nowo odkrytych ziem się rozpocząć. Tendencje te były obecne wśród pierwszych franciszkańskich misjonarzy, którzy dotarli do Ameryki i którzy byli uformowani w hiszpańskich prowincjach zreformowanych przez kardynała Cisnerosa. Chociaż L.J. Oré urodził się już na terenie Nowego Świata, to jednak jego myśl przepojona była mesjanizmem i pragnieniem urzeczywistnienia ery Ducha Świętego wśród ewangelizowanych Indian. Elementy tej utopii szczególnie łatwo można wychwycić w pierwszej części dzieła idealizującej środowisko ewangelizowanych Indian.

72 SCI: ff. 145 r. -156 v.

${ }^{73}$ SCI: f. $147 \mathrm{v}$.

${ }^{74}$ J. Heras, Aporte de los franciscanos a la evangelización del Perú, Lima 1992, s. 105-106. 
Pomimo tych elementów, które można określić jako nie w pełni ortodoksyjne, całość dzieła to przepiękny wykład tradycyjnej doktryny Kościoła, ubogacony o elementy antropologii kulturowej peruwiańskich Indian. Symbolo Catholico Indiano to bez wątpienia jeden z najważniejszych traktatów przeznaczonych dla misjonarzy ewangelizujących ludy andyjskie, który ukazał się drukiem w XVI wieku.

\section{Luis Jerónimo de Oré OFM — Symbolo Catholico Indiano (1598)}

\section{Summary}

Brother Luis Jerónimo de Oré's Symbolo Catholico Indiano was the most important and authorized sixteenth century treatise for the evangelization of the native Andean peoples. In its pages we find a vivid image of Andean reality immediately after the Conquest and a fervent exposition of the Catholic faith inspired in the recent Councils of Trent and Lima. The treatise also presents the missioning methods that served the Franciscans and other priests of the Viceroyalty for the evangelization of the indigenous peoples. Above all, in this text we find an admirable exposition of the theological doctrine and catechetical practice in the anthropological perspective that forms its starting point, which is the Andean man or woman who had never heard a message of salvation and dignity for the human person.

Brother Luis Jerónimo de Oré Rojas OFM was born in Huamanga in 1554 (now the geographical Department of Ayacucho in Perú). He was a zealous missionary who travelled throughout the colonizers' territory, from the extreme north of Florida to the extreme south of Chile. As an intelligent linguist he was the author of important rituals and catechisms in Quechua and Aymara. He was one of the first bishops born on the American soil, and the first to be incorporated into the Native Indian Council and the Vatican hierarchy; as a bishop he stood out for his protection of aboriginal groups and his energetic defense of the cultural integrity of Native Indian nations.

\section{Keywords}

catechesis, evangelisation, Latin America, indigenous peoples, franciscanism

\section{Słowa kluczowe}

katecheza, ewangelizacja, Ameryka Łacińska, ludy indiańskie, franciszkanizm 


\section{Bibliografia}

Bartra E.T., Los autores del catecismo del Tercer Concilio Límense, „Mercurio Peruano” 470 (1967), s. 359-372.

Cook N.D., Luis Jerónimo de Oré: Una aproximación, w: Symbolo Catholico Indiano. Fray Luis Jerónimo de Oré OFM - 1598. Edición facsimilar, ed. A. Tibesar, Lima 1992, s. 35-61.

Cordoba y Salinas D., Crónica franciscana del Perú, Washington DC 1957.

Durán J.G., El Catecismo del III Concilio Provincial de Lima y sus Complementos Pastorales (1584-1585). Estudio preliminar, textos, notas, Buenos Aires 1982.

Errasti M., América Franciscana. Evangelizadores e indigenistas franciscanos del siglo $X V I$, t. 1, Santiago 1986.

Geiger M., The Franciscan Conquest of Florida (1573-1618), Washington DC 1937.

Geiger M., The Martyrs of Florida (1513-1616) by Luis Jerónimo de Óre OFM translades with Notes, New York 1936.

Heras J., Aporte de los franciscanos a la evangelización del Perú, Lima 1992.

Keenan G., Tormo Sanz L., Experiencia misionera en la Florida, Madrid 1957.

Levillier R., Organización de la Iglesia y Órdenes religiosas en el Virreinato del Perú en el siglo XVI, Madrid 1919.

Levillier R., Papeles eclesiásticos de Tucumán, t. 2, Madrid 1926.

Lisson Chaves E., La Iglesia de España en el Perú, Sevilla 1940.

Lopez A., Relación histórica de la Florida escrita en el siglo XVII por Fr. Luis Jerónimo de Oré OFM, Madrid 1931.

Ocuña D., Un viaje fascinante por la América hispana del siglo XVI, Madrid 1969.

Olivares L., La Provincia franciscana de Chile, Santiago 1961.

Ovifido Cavada C., Los obispos de Chile 1561-1978, Santiago 1979.

Polo J.T., Luis Jerónimo de Oré, „Revista Histórica” 2 (1907), s. 74-91.

Symbolo Catholico Indiano. Fray Luis Jerónimo de Oré OFM - 1598. Edición facsimilar, ed. A. Tibesar, Lima 1992.

Tibesar A., Franciscan beginnings in Colonial Perú, Washington DC 1953.

Tord L.E., Luis Jerónimo de Oré y el Symbolo Catholico Indiano, w: Symbolo Catholico Indiano. Fray Luis Jerónimo de Oré OFM - 1598. Edición facsimilar, ed. A. Tibesar, Lima 1992, s. 15-34.

Vargas Ugarte R., Historia de culto de María en Iberoamérica y de sus imágenes y santuarios más celebrados, Buenos Aires 1947.

Vargas Ugarte R., Impresos peruanos (1564-1650), Lima 1953.

Wachtel N., Los vencidos. Los Indios del Perú frente a la conquista española (15301570), Madrid 1976. 